\title{
A SIMPLE DIAGNOSTIC MODEL TO ESTIMATE TOTAL SINK RECHARGE BASED ON DYE TRACING EXPERIMENTS
}

\author{
PREPROST MODEL IZRAČUNA CELOKUPNEGA NAPAJANJA \\ KRAŠKEGA SISTEMA NA OSNOVI SLEDILNE KRIVULJE
}

\author{
Hong LIU ${ }^{1}$ \& Guangquan $\mathrm{LI}^{2}$
}

\begin{abstract}
UDC 551.444

Hong Liu \& Guangquan Li: A simple diagnostic model to estimate total sink recharge based on dye tracing experiments

Dye tracing experiments are an active, effective and promising approach to investigate karst aquifers. In this paper, we develop a simple diagnostic model for calculating total recharge of sinks using dye tracing results. The conceptual model is that all sinks are convergent to a major conduit which then branches into several conduits and finally to several springs. Under the assumption that advection is dominant over dispersion at springs, breakthrough curve at a single spring can be used to calculate total recharge. The model is advantageous in that for such a conduit network, it is not necessary to measure breakthrough curves at all springs. Then the model with two dye tracing experiments is used to infer the conduit network in a karst aquifer in Luxi, southwest China. This paper represents a preliminary effort aiming to using dye tracing results to calculate the total recharge of sinks and infer the network of conduits.

Key words: sink, conduit network, spring, breakthrough curve,
\end{abstract} advection.

\begin{abstract}
Izvleček
UDK 551.444

Hong Liu \& Guangquan Li: Preprost model izračuna celokupnega napajanja kraškega sistema na osnovi sledilne krivulje

Sledenje podzemnih voda $\mathrm{z}$ umetnimi barvili je učinkovita tehnika raziskav kraških vodonosnikov. $\mathrm{V}$ članku razvijemo enostaven model za izračun celokupnega napajanja ponorov iz rezultatov sledenj. Model predpostavlja, da se voda, ki v sistem vstopa skozi več ponornih točk, najprej združi v glavnem prevodniku in kasneje razteka na več izvirov. Če predpostavimo prevladujoč advekcijski prenos sledila, lahko celokupen dotok v sistem izračunamo iz sledilne krivulje enega samega izvira. Model uporabimo pri obravnavi dveh sledenj na območju Luxi v JZ Kitajski. V članku predstavimo prve rezultate raziskav, s katerimi na osnovi sledenj poskušamo določiti celotni dotok $\mathrm{v}$ kraški sistem in sklepati o geometriji mreže kraških kanalov. Ključne besede: ponor, mreža kraških kanalov, izvir, sledilna krivulja, advekcija.
\end{abstract}

\section{INTRODUCTION}

Karst terrane is characterized by sinks or sinkholes (i.e., ponors or swallets), caves or conduits, karst windows, and springs. Surface streams in karst terranes may lose water via sinks, but gain water from springs. Most of the lost water moves underground through conduits or tunnels. Among karst features, sinks are the most important from the environmental perspective (White 1988), because if springs are used as a drinking water source, pollutants

\footnotetext{
${ }^{1}$ International Joint Research Center for Karstology, Yunnan University 5 Xueyun Rd. Kunming, Yunnan 650223, P. R. China Tel: 011-86-13013325083, Email: hongliu@ynu.edu.cn

${ }^{2}$ International Joint Research Center for Karstology, Yunnan University 5 Xueyun Rd. Kunming, Yunnan 650223, P. R. China, Tel: 011-86-13708762808, Fax: 011-86-871-65033733,Email: guangquan_li@yahoo.com, corresponding author
}

Received/Prejeto: 19.01.2015 
from surface runoffs, after entering sinks, can rapidly degrade the water quality of springs.

Typically, water flux at a sink can be measured using flow meters or weirs. However, measurement of total recharge of all sinks is difficult. The fluxes measured exactly at sinks are often smaller than the total recharge, because as streams flow on their ways to sinks, part of water is lost. The lost water still contributes to the total recharge via fractures and/or unknown sinks. On the other hand, direct measurement of fluxes at sinks requires tremendous logistical efforts, because velocities at many points on the cross section must be measured and there may be many sinks in a karst watershed (Li \& Field 2014).

There are a lot of geochemical study of karst aquifers, with a focus on the water exchange and solute transfer between solution conduits and the aquifer matrix (Martin \& Dean 2001; Screaton et al. 2004; Martin et al. 2006; Mitrofan et al. 2015). That approach is advantageous in providing reliable evidences to reveal the chemical and physical processes in the aquifers, but suffers from its limited capability to quantify the processes and to obtain the watershed-scale parameters. Mathematical modeling of physical processes, instead, can provide an important and complimentary way to study flow and transport in karst aquifers.

Dye tracing techniques can be used in all types of hydrological and hydrogeological environments to acquire information on water movement and contaminant migration (Käss 1998). Karst aquifers are difficult to conduct instrumentation or measurement in their interiors. Dye tracing experiments in which artificial tracers are purposely injected at sinks or sinkholes and then monitored at downstream springs or karst windows, represent an active way to explore the aquifers. A brief review of karst hydrogeology, dye-tracing concepts and techniques, and sources for equipment and materials, is available in a manual by Mull et al. (1988). Goldscheider et al. (2008) presented an introduction to the fundamentals of tracing techniques and their application in karst settings, illustrated by case studies from Mammoth Cave, USA, and a small experimental site in Switzerland. They also discussed the properties and limitations of the most important artificial tracers.

Tracing experiments using fluorescent dyes are the most effective and promising way to measure flow and transport parameters in a conduit system, because breakthrough curves (BTCs) measured at springs are essentially the Green's functions in the mathematical sense (Strauss 1992). The Green's function is very powerful in that for steady flows, the BTC resulting from any amount of contaminants released at sinks, with any kind of release history, can be well predicted through the convolution of the release history with the function. This was shown by theory on partial differential equations in mathematics (Strauss 1992), and more generally by theory on linear and shift-invariant systems in signal processing (Lathi 2000). Nonetheless, Field \& $\operatorname{Li}(2011)$ showed that it is impossible to invert for the history of contaminants injected at sinks directly from BTCs at springs, and therefore foreword modeling and fitting method have to be used.

Currently, the best software available for simulating BTCs from dye tracing experiments is CXTFIT (Toride et al. 1995; Field \& Pinsky 2000). The CXTFIT program is based on a two-regions non-equilibrium model (Toride et al. 1993) to describe the case where strong solute transfer prevails between mobile- and immobile-water regions. It can reproduce strong skewness and long tailing in the predicted BTCs (Birk et al. 2005; Geyer et al. 2007; Göppert \& Goldscheider 2008; Goldscheider 2008; Field \& Li 2011), but conceptually has two major disadvantages: (1) flow velocity was assumed to be a constant along the conduit; and (2) dilution by dye-free waters from other tributary conduits, any fractures and pores of the rock was ignored. Another disadvantage in the application of the CXTFIT is that it requires specification of many parameters that could lead to mathematical complications and possible errors in parameterization.

Strictly speaking, the aforementioned software can only be applied to a single conduit, and is not recommended to simulate multiple peaks in the BTCs caused by multiple pathways. For a convergent spring (i.e., several sinks connect to one spring via several conduits), the simplest way to get discharge of the spring is the mass of released dye divided by integral of the BTC at the spring, in which the shape of the curve is not concerned. $\mathrm{Li}$ (2012) proposed a more advanced procedure of calculating karst conduit fluxes using dye tracing results. The Green's function for the initial value problem was adapted by localized dilution at the juncture of conduit flows. The method utilizes the peak arrival time, time width, and amplitude of the measured BTC, and the resulting water flux is independent of conduit radius.

At present, models of spring BTCs resulting from dye tracing experiments still focus on a single conduit, and modeling of flow and transport in a network of multiple conduits remains notoriously challenging.

Ground water in karst terranes is extremely vulnerable to surface pollutants, and water protection agencies are very interested with recharge of sinks. Also, knowledge of precipitation and total recharge can help water managers delineate the area of a karst watershed, noting that recharge area is recharge volume divided by precipitation. In this paper, we are motivated to develop a simple diagnostic model in which dye tracing experiments are employed to calculate total recharge of sinks. The basic 
idea is that if the total recharge of all sinks yielded from different dye tracing experiments is consistent, then the conceptual model of conduit network is reliable. Other- wise, we would need to either adjust the network or find another cause.

\section{METHODOLOGY}

As shown in Fig. 1, the conceptual model is that all sinks are convergent to a major conduit which then branches into several conduits and finally to several springs. Water entering a sink is merged with water from other sinks at the convergence point and then at the divergence point, will be redistributed among the conduits. Accordingly, dye released at a sink is diluted at the convergence point by dye-free water from other sinks, then is redistributed at the divergence point, and eventually reaches all springs.

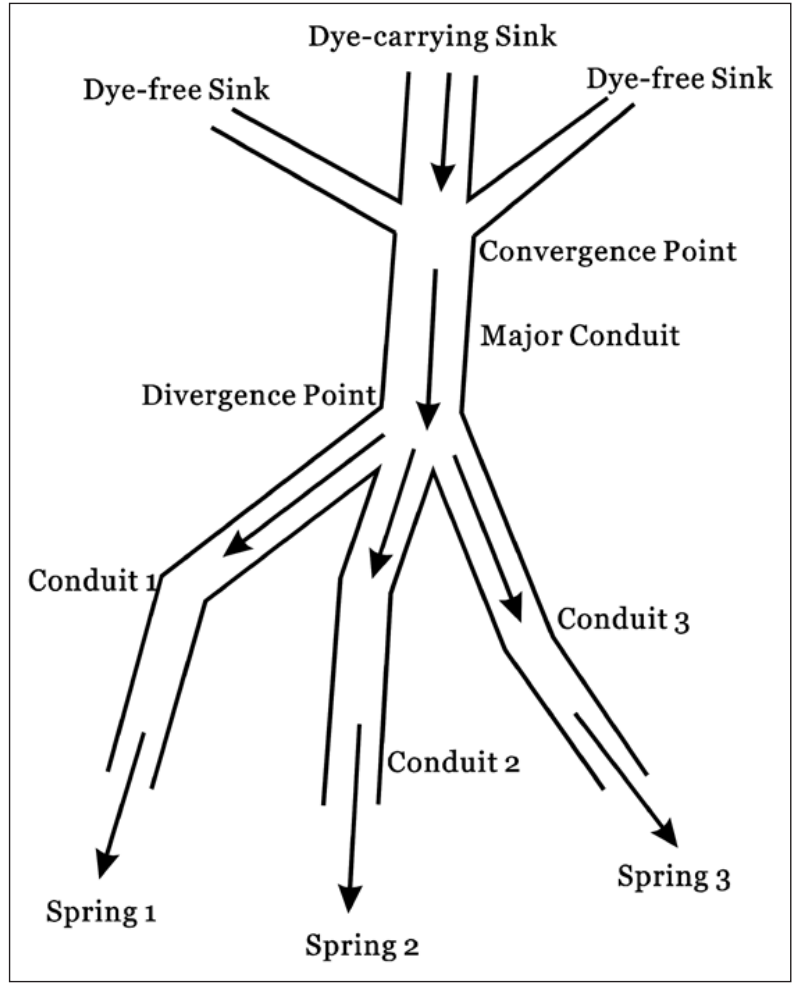

Fig. 1: A conceptual model of conduit network, in which dye is represented by black arrows. Water and dye entering a sink will be redistributed among several tributary conduits and eventually reach several springs.

Because springs are typically far from sinks, transport at springs is often dominated by advection such that

$$
m_{i}=Q_{i} \int C_{i}(t) d t
$$

where $m_{i}[\mathrm{M}]$ is the mass of dye transported within the i-th conduit (Fig. 1), $Q_{i}\left[\mathrm{~L}^{3} / \mathrm{T}\right]$ and $C_{i}(t)\left[\mathrm{M} / \mathrm{L}^{3}\right]$ are the water discharge and the dye concentration at the corresponding spring, respectively.

At the convergence point, dye-free water from other sinks dilutes the dye from the dye-carrying sink. However, this mixing-dilution won't change the total mass of dye. At the convergence point, the mixingdilution is very complicated, and the dye is typically not distributed uniformly on the cross section of the major conduit immediately following the convergence point. This (non-uniformly distributed on the cross section) fact theoretically increases dispersion of the dye. This is somewhat similar to the fact that dispersivity in a laminar pipe flow is larger than that in a turbulent pipe flow where velocity is more uniform. Nevertheless, such mechanism appears only near the convergence point. If a spring is far away from the convergence point, transverse dispersion will make the dye uniform on the spring cross section, thus causing advection to dominate over longitudinal dispersion at the spring.

Dye entering at a sink will be redistributed among the conduits at the divergent point. It is reasonable to assume that the mass of the dye in each conduit is proportional to the discharge of the corresponding spring, i.e.

$$
m_{i}=\gamma Q_{i}
$$

where $\gamma$ is a proportional factor (a constant independent of conduits).

Substituting Equation (1) into Equation (2) yields

$$
\gamma=\int C_{i}(t) d t
$$

which states that the integral of the BTC at each spring is a constant (independent of springs).

Mass conservation of dye requires

$$
\sum_{i} m_{i}=M
$$

where $M[\mathrm{M}]$ is the total mass of dye released, which is known a priori. 
Substituting Equation (1) into Equation (4) yields

$\sum_{i} Q_{i} \int C_{i}(t) d t=M$

Substituting Equation (3) into Equation (5) yields

$\sum_{i} Q_{i}=\frac{M}{\gamma}=\frac{M}{\int C_{i}(t) d t}$,

Here, by convention, $C_{i}(t)$ is the concentration at the $\mathrm{i}$-th spring where dye is sampled. The left-hand side of Equation (6) is the total discharge from all springs (including unknown springs).

Generally, exchange of water between a conduit and the surrounding rock is not zero ( $\mathrm{Li}$ 2004; Li et al. 2008). However, in some areas like Yunnan, China, carbonate rock is telogenetic rather than eogenetic, such that the exchange of water between conduits and the aquifer matrix is very limited. Therefore, it is a reasonable assump- tion that in such an area, the net exchange between a conduit and the surrounding rock is small compared to the spring discharge. Thus water flux entering a conduit will be approximately equal to discharge of the associated spring. The above assumption that the mass of dye in a conduit is proportional to the discharge of the spring will become that the mass of dye allocated to a tributary conduit is proportional to the water flux into that conduit, which is pretty reasonable. Also, the total recharge of all sinks, $Q R$, satisfies

$$
Q_{R}=\sum_{i} Q_{i}=\frac{M}{\int C_{i}(t) d t},
$$

from which the total recharge can be calculated from the integral of the BTC at a (single) spring. That is, for the above conceptual model, it is not necessary to sample dye at all springs.

\section{A CASE STUDY}

In this section, we first introduce hydrogeology of a karst watershed near Pinghaizi Reservoir in Luxi County, southwest China. Then results of two dye tracing experiments conducted there are used to calculate the total recharge of sinks and to diagnose the network of conduits in that aquifer.

Pinghaizi Reservoir is a small reservoir located in Luxi County, Yunnan, southwest China (Fig. 2). To its south is Nanpanjiang River. The reservoir is in a solution depression, having a volume of $7.2 \times 10^{6} \mathrm{~m}^{3}$. The supply of water in the reservoir comes from an artificial tunnel. The rock is dominantly limestone and karst there is well developed, manifested by several large sinkholes and springs. Water discharges from the springs and finally to Nanpanjiang River. Because of this, water in the reservoir can lose to the springs and the water storage condition is not good for further expansion of the reservoir, although the supply is good and the depression is large.

As shown in Fig. 2, Sinkholes 14 and 15 are two large sinkholes to the south of Pinghaizi Reservoir, and Sinkholes 19-31 are small sinks. There are several springs between the reservoir and Nanpanjiang River, namely, Springs 5-9, Spring 10, Spring 11 (at the upstream of XiaoJiang River), and Maoshuidong Spring. On Mar 19, 2012 (a dry season), Engineer Guoan Huang measured the water fluxes at these sinkholes and springs; see results in Table 1.

On Apr 10, 2012, we did a preliminary geochemical analysis of water in the reservoir, water at the sinkholes, and water at the springs. An important finding was that Sinkholes 19-31, Karst Window 1, and Springs 7, 8 and 10 all have an electric-conductivity of water close to that in the reservoir, whereas Spring 11 and Maoshuidong Spring have a lower electric-conductivity. It was concluded that Spring 11 and Maoshuidong Spring come from a source other than the reservoir and they are not well connected with the sinks. On Apr 20-22, 2012, karst experts from Slovenia Academy of Science and the authors conducted a cooperative study of geochemical features of water in the reservoir, water at Karst Window 1, Springs 8, 10 and 11, and Maoshuidong Spring, which led to the same conclusion. Moreover, the concentration of nitrate at Spring 11 and Maoshuidong Spring was found to be significantly lower than that in the reservoir, Karst Window 1, and Springs 8 and 10. Actually, Spring 11 and Maoshuidong Spring are in a different watershed, separated from Pinghaizi Reservoir by a mountain. Water in the reservoir is through the urban

Tab. 1: Parameters of flow in a dry season, measured on Mar 19, 2012.

\begin{tabular}{lcc}
\hline Parameter & Value & Units \\
\hline Sinkholes 14 and 15 & 0.0 & $\mathrm{~m}^{3} / \mathrm{s}$ \\
\hline Sinkholes 19-31 & 0.020 & $\mathrm{~m}^{3} / \mathrm{s}$ \\
\hline Maoshuidong Spring & 0.033 & $\mathrm{~m}^{3} / \mathrm{s}$ \\
\hline Spring 11 & 0.002 & $\mathrm{~m}^{3} / \mathrm{s}$ \\
\hline Spring 10 & 0.030 & $\mathrm{~m}^{3} / \mathrm{s}$ \\
\hline Spring 8 & 0.001 & $\mathrm{~m}^{3} / \mathrm{s}$ \\
\hline Springs 5, 6, 7,9 & 0.0 & $\mathrm{~m}^{3} / \mathrm{s}$ \\
\hline
\end{tabular}




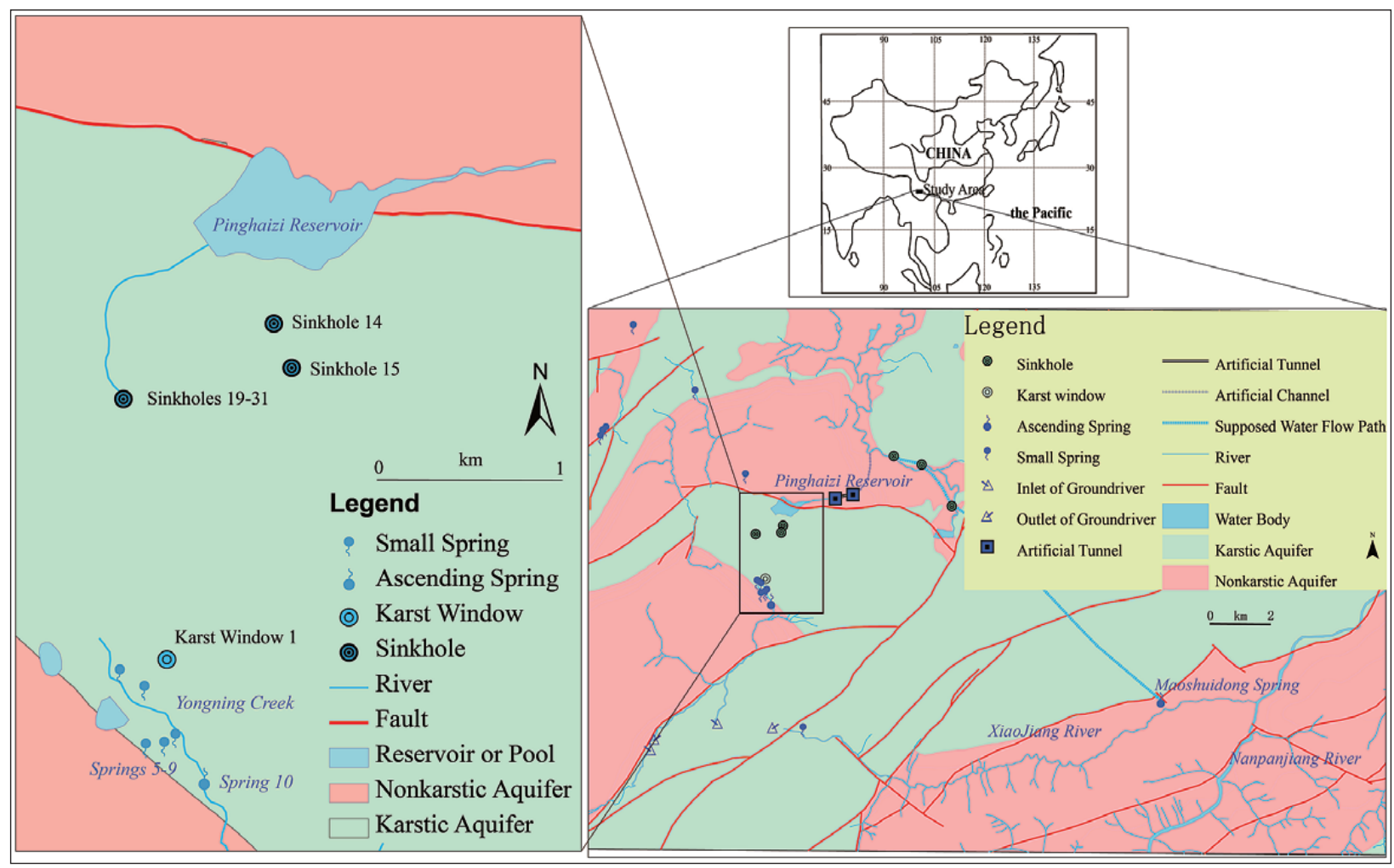

Fig. 2: Hydrogeologic map of the study area.

part of Luxi County, thus having a higher concentration of pollutants and a higher electric-conductivity. For these reasons, Spring 11 and Maoshuidong Spring, though having a large discharge, were anticipated not to receive dye in our dye tracing experiments.

We conducted two dye tracing experiments beginning on Aug 30, 2012. The sampling intervals ranged from 2 to 12 hours. The accuracy of dye concentration was $0.1 \mathrm{ppb}$. Small glass bottles preprocessed by distilled water were used to get and store water onsite, which was then analyzed using a scanning spectrofluorophotometer at Karst Laboratory of Yunnan University.

In the first experiment, Rhodamine B (with a mass of $4.7 \mathrm{~kg}$ ) was released at Sinkhole 14. In the second experiment, Uranine (with a mass of $3.5 \mathrm{~kg}$ ) was released at Sinkhole 15. Sampling locations were Karst Window 1, Spring 10, Spring 11 and Maoshuidong Spring. The whole experiments last from August 30 through September 29. As anticipated, dye was successfully monitored at Karst Window 1 and Spring 10, but not at Spring 11 or Maoshuidong Spring. As shown in Fig. 2, dye might enter Yongning Creek (upstream of Spring 10) via Springs 5-9. However, Springs 5-9 are small springs which only have a very small discharge. As such, the complication brought by those small springs can be well neglected.

The model in the preceding section is now used to diagnose the network of conduits, i.e., whether Sink-

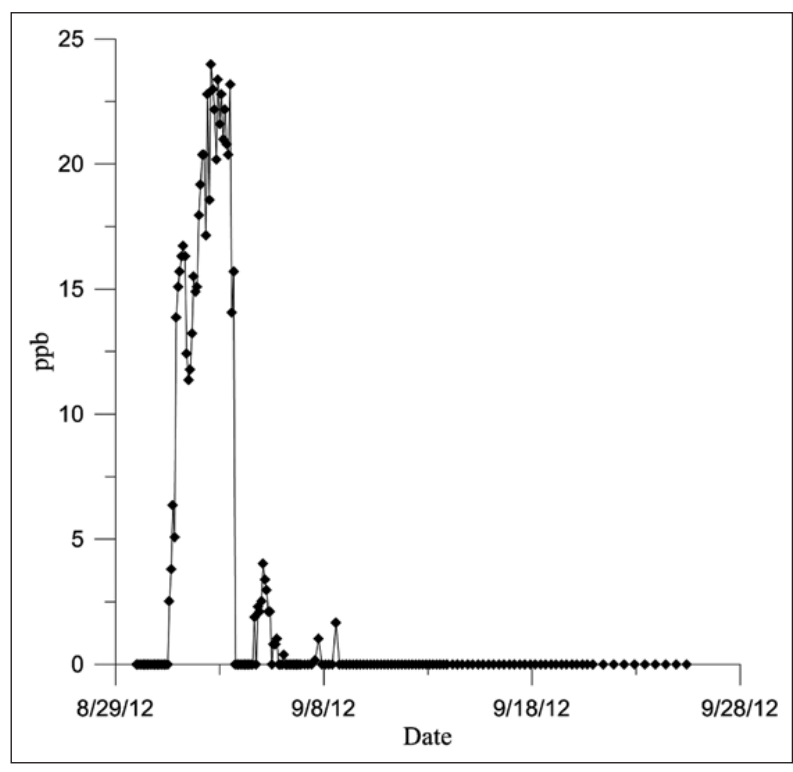

Fig. 3: Breakthrough curve of Rhodamine B released at Sinkhole 14 and sampled at Karst Window 1.

holes 14, 15, and 19-31 are merged into a major conduit and then diverges to the springs. The integral of the BTC of Rhodamine B released at Sinkhole 14 and monitored at Karst Window 1 (Fig. 3) is used as the first to calculate the recharge. The integral with respect to time 


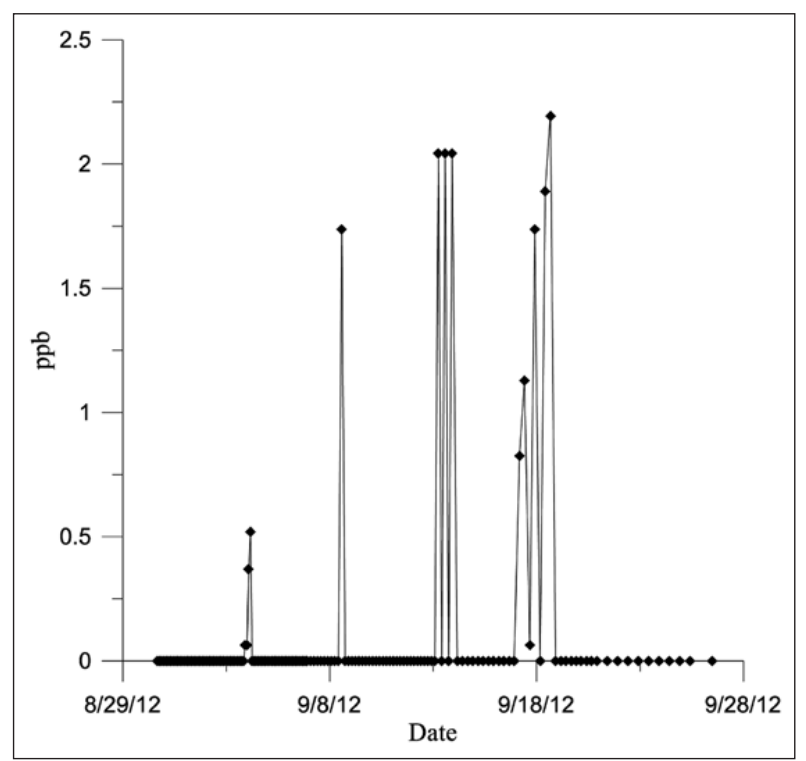

Fig. 4: Breakthrough curve of Uranine released at Sinkhole 15 and sampled at Karst Window 1.

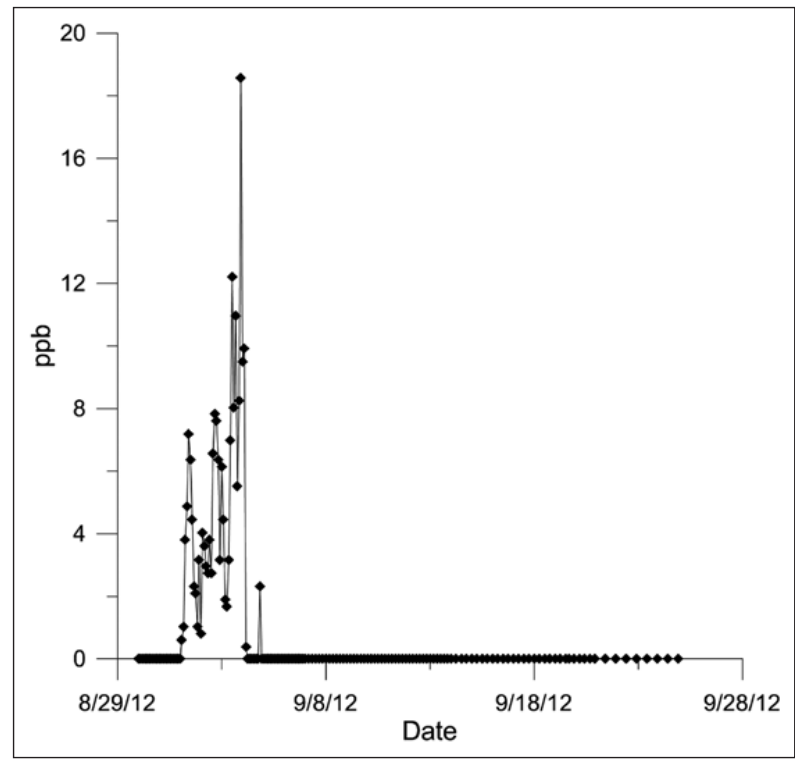

Fig. 5: Breakthrough curve of Rhodamine B released at Sinkhole 14 and sampled at Spring 10.

is $1.34 \times 10^{-3}$ hour.g/l. Using Equation (7) yields a sink recharge $0.97 \mathrm{~m}^{3} / \mathrm{s}$.

The integral of the BTC of Uranine released at Sinkhole 15 and monitored at Karst Window 1 (Fig. 4) is also used to calculate the recharge. The integral with respect to time is $80.5 \times 10^{-6}$ hour.g/l. Using Equation (7) yields a sink recharge $12.1 \mathrm{~m}^{3} / \mathrm{s}$, which is unreasonably large. We shall explain this in Discussion.

For Spring 10, the sampled water is a mixture between the dye-carrying water of the spring and the

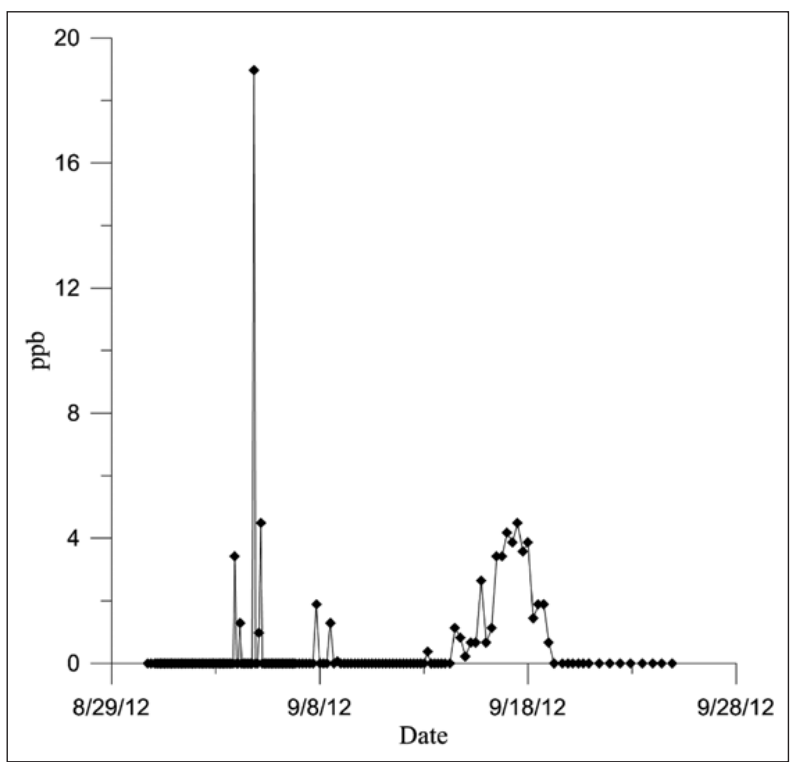

Fig. 6: Breakthrough curve of Uranine released at Sinkhole 15 and sampled at Spring 10.

dye-free water in Yongning Creek. For this reason, we need to modify Equation (7) into

$$
\frac{Q_{S 10+C}}{Q_{S 10}} Q_{R}=\frac{M}{\int C_{S 10+C}(t) d t},
$$

where $Q_{S 10+C}$ and $C_{S 10+C}$ are the combined flux of Spring 10 and the creek and the concentration of the merged water, respectively; $Q_{S 10}$ the discharge of Spring 10. The flux of the creek was estimated onsite to be two times the discharge of Spring 10 (The vent of Spring 10 is at the bed of the creek such that it is impossible to directly measure the spring discharge). Thus

$$
Q_{R} \approx \frac{1}{3} \frac{M}{\int C_{S 10+C}(t) d t}
$$

Fig. 5 shows the BTC of Rhodamine B released at Sinkhole 14 and sampled at Spring 10. The integral with respect to time is $3.98 \times 10^{-4}$ hour.g/l. Using Equation (9) yields a total recharge $1.09 \mathrm{~m}^{3} / \mathrm{s}$. For the dye tracing experiment in which a mass of Uranine of $3.5 \mathrm{~kg}$ was released at Sinkhole 15. The integral of the BTC sampled at Spring 10 (Fig. 6) with respect to time is $316.5 \times 10^{-6}$ hour.g/l. Using Equation (9) yields a total sink recharge $1.02 \mathrm{~m}^{3} / \mathrm{s}$. 


\section{DISCUSSION}

For the first experiment in which Rhodamine B was released at Sinkhole 14, samplings at Karst Window 1 and Spring 10 yield a total recharge of 0.97 and $1.09 \mathrm{~m}^{3} / \mathrm{s}$, respectively. For the experiment in which Uranine was released at Sinkhole 15, samplings at Spring 10 yields a total recharge of $1.02 \mathrm{~m}^{3} / \mathrm{s}$. This consistency in the total recharge indicates that our model is applicable for the experiments and the framework of conduits should be similar to that depicted in Fig. 1.

We observed that the flow at Sinkhole 15 after dye releasing was very small, such that a significant part of dye was in a perched state. Nonetheless, almost all Uranine eventually reached Spring 10, because the recharge calculated is very consistent with that from the Rhodamine B experiment.

However, for the second experiment in which Uranine was injected at Sinkhole 15, the sampling at Karst Window 1 yields a sink recharge of unbelievable $12.1 \mathrm{~m}^{3} / \mathrm{s}$. This shows that the model depicted in Fig. 1 is not completely applicable. The most likely reason is that the point where the tributary conduit from Sinkhole 15 merges to the major conduit is very close to the point where the small conduit to Karst Window 1 diverges from the major conduit (Fig. 7). As such, dye from Sinkhole 15 tended to move on one side of the major conduit and was unlikely to enter the tributary conduit on the other side (the small flux from Sinkhole 15 is also a factor), causing only a very small quantity of dye to reach Karst Window 1. This shows that if dye reaches a divergence point immediately after a convergence point, water will be not well mixed in such a short distance and thus dye will not be redistributed as predicted by the model. This scenario is in essence a singularity, i.e., the real mixing and transport at a divergence point immediately after a convergence point is so difficult to describe that our simple model is not valid. Nonetheless, for transport of dye along the major conduit (i.e., from Sinkhole 14 to Spring 10), because the water flux from Sinkhole 15 is small, the aforementioned complexity vanished to a large extend such that our model works well.

As listed in Table 1, the total recharge to all sinks and the discharge of springs (excluding Maoshuidong Spring and Spring 11 that are not hydraulically connected to the sinks) on Mar 19, 2012 were 0.020 and $0.031 \mathrm{~m}^{3} / \mathrm{s}$, respectively. Especially, Sinkholes 14 and 15 were not activated at that time. In contrast, the total recharge to all sinks in September is $1.03 \mathrm{~m}^{3} / \mathrm{s}$ on average, much larger than that in March. This appears to be reasonable because September is in a monsoon season of Yunnan and precipitation in September is much larger than that in March.
Whether in March or in September, discharge from Springs 5-9 in Fig. 2 is much smaller than that of Spring 10. Therefore, Spring 10 is the major outlet of ground water in the study area. The difference is that in March (a dry season), the major recharge is through Sinkholes 19-31, while in September (a flooding season) the major inlet is Sinkhole 14.This shows that the redistribution of recharge among sinks in the study area does not satisfy similarity. In other words, Sinkhole 14 is not activated in a dry season but becomes activated in a flooding season.

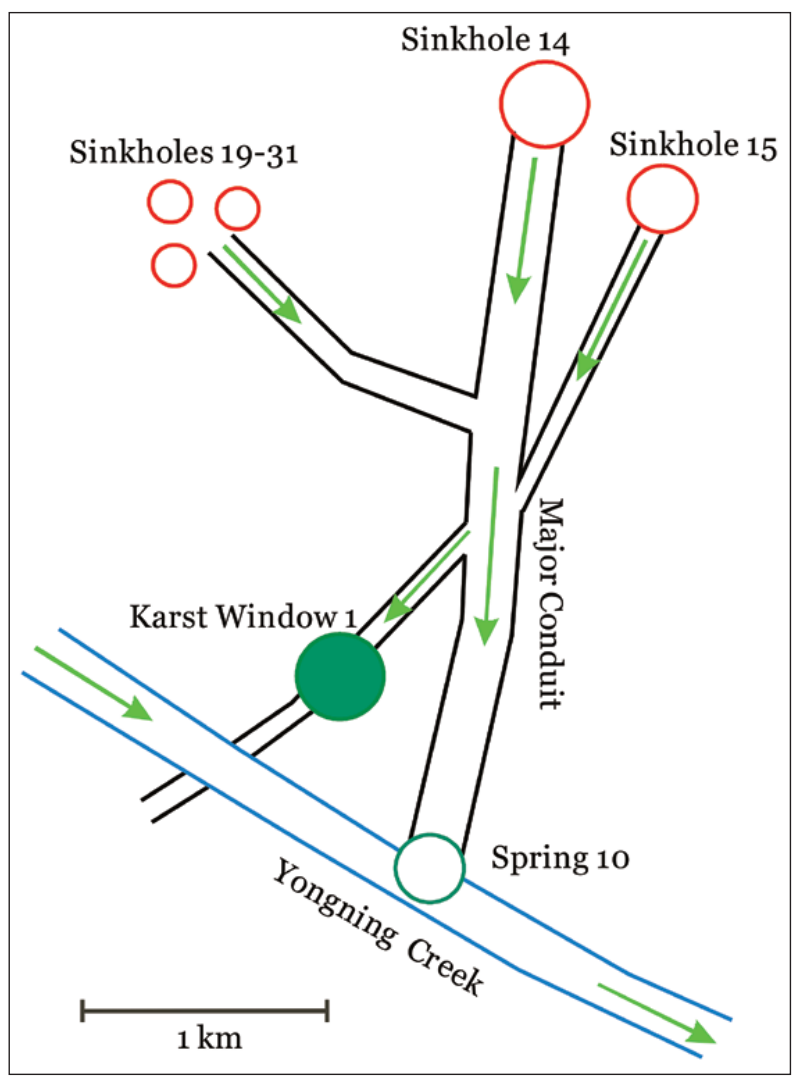

Fig. 7: Inferred conduit network near Pinghaizi Reservoir. The point where the tributary conduit from Sinkhole 15 merges to the major conduit is adjusted to be close to the point where the conduit to Karst Window 1 diverges from the major conduit, and this can interpret the unbelievable recharge calculated from the BTC of Uranine at Karst Window 1 yielding from the release at Sinkhole 15.

The above fact can be explained using the Manning Equation (Chow 1959). For simplicity, we apply the Manning Equation to the major conduit where water is semi-saturated (like an open channel), while other small conduits are phreatic and fracture-like. For the small conduits and fractures, the water flux is proportional to the hydraulic slope and to their cross sections. In con- 
trast, the flux in the major conduit is proportional to the square root of the hydraulic slope and approximately to the cube of the effective radius. When the sink recharge increases, the hydraulic slope will increase only slightly and thus can be well assumed to be a constant (as the first order approximation). Therefore, the flux in the small conduits and fractures are almost unchanged, because their cross sections is fixed (phreatic). In contrast, the major conduit (semi-saturated and like an open channel) allows for a significant increase of flux within it, because its effective radius can increase. This leads to that the increased portion of the recharge is mostly allocated to the major conduit. In other words, with the increase of recharge, the major conduit will share more portion of the sink water. That is why in our study, the major conduit from Sinkhole 14 to the convergence point (see Fig. 7) that only share a small portion of the sink recharge in a dry season becomes sharing a much larger portion of the sink water during a flooding season.

\section{CONCLUSIONS}

We developed a diagnostic model for calculating total recharge of all sinks using dye tracing results, based upon the conceptual model that all sinks are connected to a major conduit which branches into several conduits and finally to several springs. As such, dye released at a sink is diluted by dye-free water from other sinks and will reach the springs via several conduits. The model allows us to use integral of the BTC at a spring to calculate the total recharge of sinks. Such a model is advantageous in that for the conduit network, it obviates the need for measuring BTCs at all springs, which is much more costly to conduct.

The model, together with the results from two dye tracing experiments, was used to diagnose the network of karst conduits near Pinghaizi Reservoir, Luxi, China. Three BTCs yielded a consistent total recharge of sinks. The unbelievable recharge $\left(12.1 \mathrm{~m}^{3} / \mathrm{s}\right)$, calculated from one BTC at Karst Window 1 (Fig. 4) made us adjust the conduit network accordingly. That singularity of conduit structure may also be responsible for the high variation of dye concentration with time in Fig. 4. The conduit network inferred finally is robust in that the sink recharges yielding from the two experiments (each having two sampling locations) were well interpreted.

A distinct feature of the observed BTCs in this paper was the presence of multiple peaks with different arrival times. This may imply that the major conduit has several bypasses. Nonetheless, the possible bypasses can be combined to consist in a visual major conduit. The total mass of dye transported within the visual major conduit would keep the same, thus not affecting the total sink recharge calculated. Our future work would be an attempt to resolve the bypasses of the major conduit.

\section{ACKNOWLEDGMENTS}

Funding support of this research was provided by National Science Foundation of China under grant 41371040 and grant 41162008 . We are deeply grateful to Editor-in-
Chief Franci Gabrovšek and one anonymous reviewer for their insightful comments and constructive suggestions.

\section{REFERENCES}

Birk, S., Geyer, T., Liedl, R. \& M. Sauter, 2005: Processbased interpretation of tracer tests in carbonate aquifers.- Ground Water, 43(3), 381-388, doi: 10.1111/j.1745-6584.2005.0033.x.
Chow, V., 1959: Open-channel Hydraulics. New York, McGraw-Hill, 680 pp. 
Field, M. \& P. Pinsky, 2000: A two-region nonequilibrium model for solute transport in solution conduits in karstic aquifers.- Journal of Contaminant Hydrology, 44(3-4), 329-351.

Field, M. \& G. Li, 2011: Inversion for the input history of a dye tracing experiment.- Journal of Cave and Karst Studies, 73(1), 16-20, doi: 10.4311/jcks2010es0143.

Geyer, T., Birk, S., Licha, T., Liedl, R. \& M. Sauter, 2007: Multitracer test approach to characterize reactive transport in karst aquifers.- Ground Water, 45(1), 36-45, doi: 10.1111/j.1745-6584.2006.00261.x.

Goldscheider, N., 2008: A new quantitative interpretation of the long-tail and plateau-like breakthrough curves from tracer tests in the artesian karst aquifer of Stuttgart, Germany.- Hydrogeology Journal, 16, 1311-1317, doi: 10.1007/s10040-008-0307-0.

Göppert, N. \& N. Goldscheider, 2008: Solute and colloid transport in karst conduits under low- and highflow conditions.- Ground Water, 46(1), 61-68, doi: 10.1111/j.1745-6584.2007.00373.x.

Goldscheider, N., Meiman, J., Pronk, M. \& C. Smart, 2008: Tracer tests in karst hydrogeology and speleology.- International Journal of Speleology, 37(1), 27-40.

Käss, W., 1998: Tracing Technique in Geohydrology. Rotterdam, Balkema, 600 pp.

Lathi, B., 2000: Signal Processing and Linear Systems. New York, Oxford University Press, 864 pp.

Li, G., 2004: Laboratory simulation of solute transport and retention in a karst aquifer. Ph.D. Dissertation, Florida State University, Tallahassee, Florida.

Li, G., Loper, D. \& R. Kung, 2008: Contaminant sequestration in karstic aquifers: Experiments and quantification.- Water Resources Research, 44, W02429, doi: 10.1029/2006WR005797.

Li, G., 2012: Calculation of karst conduit flow using dye tracing experiments.- Transport in Porous Media, 95, 551-562, doi: 10.1007/s11242-012-0061-6.

Li, G. \& M. Field, 2014: A mathematical model for simulating spring discharge and estimating sinkhole porosity in a karst watershed.- Grundwasser, 19, 51-60, doi: 10.1007/s00767-013-0243-3.
Martin, J.B. \& R.A. Dean, 2001: Exchange of water between conduits and matrix in the Floridan Aquifer.- Chemical Geology, 179, 145-166, doi: 10.1016/ S0009-2541(01)00320-5.

Martin, J.M., Screaton, E.J. \& J.B. Martin, 2006: Monitoring well responses to karst conduit head fluctuations: Implications for fluid exchange and matrix transmissivity in the Floridan aquifer. In: Wicks, C.M., Harmon, R.S. (Eds.), Perspectives on Karst Geomorphology, Hydrology, and Geochemistry: A Tribute Volume to Derek C. Ford and William B. White. Geological Society of America, Boulder, Colorado, pp. 09-217.

Mitrofan, H., Marin, C. \& I. Povară, 2015: Possible conduit-matrix water exchange signatures outlined at a karst spring.- Ground Water, 53, 113-122, doi: 10.1111/gwat.12292.

Mull, D., Liebermann, T., Smoot, J. \& L. Woosley, 1988: Application of dye-tracing techniques for determining solute-transport characteristics of ground water in karst terranes. U.S. Environmental Protection Agency Region 4, Atlanta, Georgia, Publication EPA 904/6-88-001, 103 pp.

Screaton, E., Martin, J.B., Ginn, B. \& L. Smith, 2004: Conduit properties and karstification in the Santa Fe river sink-rise system of the Floridan aquifer.Ground Water,42, 338-346, doi: 10.1111/j.17456584.2004.tb02682.x.

Strauss, W., 1992: Partial Differential Equations: An Introduction. New York, John Wiley \& Sons, 425 pp.

Toride, N., Leij, F. \& M. van Genuchten, 1993: A comprehensive set of analytical solutions for nonequilibrium solute transport with first-order decay and zero-order production.- Water Resources Research, 29(7), 2167-2182.

Toride, N., Leij, F. \& M. van Genuchten, 1995: The CXTFIT code for estimating transport parameters from the laboratory or field tracer experiments; version 2.0. US Salinity Lab. Res. Rep. 137, Riverside, Calif., $121 \mathrm{pp}$.

White, W., 1988: Geomorphology and Hydrology of Karst Terrains. New York, Oxford University Press, 464 pp. 